\title{
Project-based learning and student development skills
}

\author{
Elvira Mullai, PhD Cand. \\ European University of Tirana, Albania
}

\begin{abstract}
This study presents the results of a research work, which aims to highlight the benefits of learning through projects in the development of cognitive and psycho-social skills of students. Project-based learning is a contemporary teaching method where students work on a project about a topic or a particular problem that seeks to develop a variety of learning skills such as cognitive skills, social and collaborative skills, self-affirmative and leadership skills. To accomplish this work, students rely on prior knowledge of the subject and in-depth research on issues to be answered. The purpose of this paper is to highlight the positivity that the projected hours for the development of the special potentials the students have, aiming at the successful inclusion of students in the learning process. To substantiate the problem, we have also raised the research question: How does project work affect the students learning, leadership and social skills? To answer the research question of this study, we have raised the hypothesis that project work encourages the development of student learning, leadership and social skills. We have proved this problem through a qualitative observation method that was realized with the students of the eighth grade in the 9-year school "Abdulla Hida" in Elbasan, in the interlocutor project hours. From the results of the research we have come to the conclusion that through project-based learning is achieved the cognitive, social and self-empowering development of students.
\end{abstract}

Keywords: project-based learning, cognitive development, social development, self-promotion of the individual

\section{Introduction \\ Learning with projects}

Project learning is a contemporary method that includes multiple learning abilities, such as cognitive ability, social and collaborative skills, self-affirmative and leadership.

Project-based learning is a teaching method where students work on a project about a topic or about a particular problem. To accomplish this work, students rely on preliminary knowledge about the subject and in-depth research on issues to be answered.

Through this teaching method, the aim is to deepen the knowledge of the classroom students and to apply them in practice. At the center of this research work is collaborative work between students, who work together in groups, focusing on individual jobs and shared tasks.

Project learning integrates theory with practice. Pupils receive knowledge and core curriculum elements, but they also apply their knowledge in solving authentic problems and achieving the right results. Project learning refocuses the education of students with the right skills that the global world requires, such as creativity, sensitivity and elasticity, which can not be taught by a text, but must be activated through practice ${ }^{1}$.

Project-based learning is a comprehensive perspective, focused on learning the students involved in the research. Within this framework, students pursue problem solving, seeking and processing questions, debating ideas, making predictions,

\footnotetext{
1 Blumenfeld et al 1991, EDUCATIONAL PSYCHOLOGIST, 26(3\&4) 369-398 "Motivating Project-Based Learning: Sustaining the Doing, Supporting the Learning." Phyllis C. Blumenfeld, Elliot Soloëay, Ronald Ë. Marx, Joseph S. Krajcik, Mark Guzdial, and Annemarie Palincsar.
} 
compiling plans and experiments, collecting and processing data, drawing conclusions, communicating their ideas to others ${ }^{1}$.

Project-based teaching has the following advantages:

- Deep understanding of concepts;

- A wider knowledge base;

- Improving writing skills;

Social, interpersonal and improved communication skills

Through project learning, students need to organize their work and manage the time needed for each stage of the project. Students become active digital explorers. Technology enables students to think actively about the choices they make and execute. Each student is likely to be included individually or as a group.

Project Learning supports student groups who identify a topic or problem around which they will investigate problem solving.

Project-based learning is of particular importance to these components:

- The main content of the project;

- Key Project Competencies;

- Deep research into the topic selected for the project;

- Building the questions. Each research is based on one or more research questions, so their construction is important for designing the project structure;

- Choices and decisions of students around time, resources, etc.

- Review the work done step by step by students about the project;

How can we plan a project-based learning activity (MBP)

Selecting the topic is one of the most important moments, as the topic needs to fill some mitigating conditions, such as: the topic should be interesting to the students; - have space and opportunity for information; to fit certain age groups, given their level of knowledge.

\section{Learning in collaboration}

Based on project-based learning is learning in collaboration. According to Stevens \& Slavin (1995), learning in co-operation increases the learning outcomes of students of all levels of ability, reading, writing, math, calculus and mathematical applications, in understanding and critical thinking ${ }^{2}$.

Learning in co-operation improves interpersonal relationships, improving students' emotional status, self-assessment, coping skills, and attitudes to school tasks. (Musai, 2014, 279)

According to B. Musai, collaborative learning:

- Improves understanding of the content of the subject;

- Improves social habits;

- Encourages student decision-making abilities;

- $\quad$ Creates an active learning environment;

- Increases student self-confidence;

- $\quad$ Assess the different ways of learning;

- Increases student responsibility;

${ }^{1}$ B. Musai, Metodologjia mësimore $(2014,278)$

2 B. Musai, metodologji e mësimdhënies $(2014,278)$ 
- It focuses on everyone's success. (Musai, 2014, 279)

According to Sharon (1995), the characteristics of learning in collaboration are:

- Use small groups of three or four students;

- It focuses on tasks to be carried out;

- Requires collaboration and communication of the group;

- Provides individual responsibility for learning;

- $\quad$ Supports group compactness ${ }^{1}$

\section{The role of teachers in project-based learning:}

In cooperative teaching, the role of the teacher does not fade. He is the organizer or conductor of the lesson.

- Teacher is a partner in communication and interaction in class

- Teacher reduces the level of stress and workload during an activity, teaching them to help each other in the tasks assigned

- $\quad$ Teacher provides advice on the activities that the learner will develop

- Teacher encourages pupil-student action

- Teacher acknowledges student feedback about the method to be developed and creates the opportunity for the student to be free to inquire

- $\quad$ The teacher exercises the students for an independent evaluation of achievements in their activities

\section{The role of student in project-based learning:}

- Pupils are actively involved in the learning process and with interactive methods students have the right to take initiatives

- $\quad$ Students join initiatives

- The students speak on behalf of the group in which they perform the job

- Set certain rules for certain situations

- Create new communication relationships with each other

- Increase the quality of classroom learning

The rapid changes in society undoubtedly brought about the need for changes in our education system as well. Change in the education system is obvious. The curriculum is based on competencies, where emphasis is placed on developing students' skills, attitudes and knowledge.

In Europe, the European Commission has developed "Essential Competences for a Knowledge-based Society" that defines the knowledge, skills and attitudes of the 21st century. These can be found in EC 2004 report.

\section{Competencies:}

1. Communication and expression competence;

2. Competence of thinking;

3. Learning competence;

4. Competence for life, work and the environment;

5. Personal competence;

6. Civil Competence;

7. Digital Competence.

${ }^{1}$ Banks, T. (2000). Teaching learning process. Center for Aide Regulation and education. North Carolina 
The development of these competences is achieved through cooperative teaching, with the student centered, which requires mutual teacher and student engagement and cooperation. In contrast to teacher-centered teaching, studentcentered teaching makes the student not to remain a passive audience, but makes the student an active thinker and researcher.

While Kolbi (1984) puts the student at the center of learning, evaluating his participation in the learning process as crucial to his learning experience. Silcock and Brundert (2001) defined the teaching with center the student as an approach where the teacher is facilitating and guiding the learning process towards the teaching where the teacher exercises control in each direction for achieving the learning objectives. One of the most common activities in the classroom that is in fact the basis of all learning and education activities is communication between teachers and students. It is implemented in many forms throughout the classroom and involves directly or indirectly all students. It aims at improving the quality of teaching.

According to Banks ${ }^{1}$, teaching is an active process in which a person shares information with others to provide them with knowledge, which lead the behavioral changes. Rather ${ }^{2}$ emphasizes that teaching is a tripartite process, involving the teacher, the student, and the learning situation and leading to changing student behavior. Student-centered learning is part of contemporary, interactive, comprehensive learning strategies, methods and techniques.

Some of the features of this process are:

a. The basic function of this lesson is learning, which in this case has a wide understanding and includes all learning models such as fact preservation, modeling, critical thinking, integrated learning, global education, learning with projects and so on.

b The student-centered teaching is distinguished by its asymmetrical nature, which includes the interaction between mature individuals and those of those who have high level of general development and those with low level of development.

c The student-centered teaching is organized around some knowledge that may be conceptual knowledge, practical knowledge, skills and abilities, procedural knowledge, etc. Schematically, a simple student-centered teaching model would be;

\section{Methodology}

The study is based on the importance of project-based learning as a contemporary and effective method of student learning, the implementation in practice and the comprehensive education of students.

This study is based on the challenges of today's education, which must respond to the challenges of human society in the face of global change. The proper education and education of students today makes them worthy citizens of tomorrow's global society, with creative minds in the face of information and communication technology developments. This tomorrow's mission, alongside various factors, can also be achieved through project-based learning, where knowledge-practicing weaving is given priority.

The study was raised around the research question:

How does project work affect student learning, leadership and social skills?

To answer the research question, we have raised the hypothesis that: Project work fosters the development of student learning, leadership and social skills.

The research was conducted through a simple survey method, which was realized in 8th grade students of the 9-year school "Abdulla Hida" in Elbasan. The survey was carried out in 3 hours of inter-project, on topic selection time, on assignment of tasks and on project presentation time.

The survey was conducted through the registration of project hours. For this, I need permission from the school board.

\section{Purpose of survey application:}

\footnotetext{
${ }^{1}$ Rather A. R. (2004). Essentials Of Instructional Technology. Publisher, Discovery Publishing House

${ }^{2}$ Constitution from the 17th of February 1994, published on http://mjp.univ-perp.fr/constit/be1994-0.htm
} 
- Evidence of how the project hours are realized;

- Evidence of innovations that bring learning through projects as one of the contemporary methods, based on which theorypractice co-ordination lies.

\section{Sampling}

In this study were attended by 14 students of the seventh grade. Of these, 8 students are female and 6 students are male. Also, out of the total number of students, it is noticed that students are of different levels of learning outcomes. Since the project was interlinked, it was a good opportunity to look at the students at different levels involved in the different trends in the project.

The students were grouped into four groups, namely: 1- a group of languages and literature that worked on gathering the traditions and customs of the area, with regard to celebrations and hospitality; 2- the collection of traditional song songs; 3the group that took care to paint the traditional costumes of the area; 4-story group that gathered stories and legends from the history of the area.

Since the project was interlinked, the study included 4 teachers, namely subjects: Albanian language, history, music education, figurative education

The theme of the project was "Our Popular Traditions and Customs".

The study belongs to the "Abdullahida" school, a common public school.

\section{Practical Findings}

Theories from the theory help us to focus on focusing on field research, specifically, the observation, the subjects and goals of the survey, the way the survey is conducted, the observation time span.

Starting from the discovery of videos recorded during the survey, the following findings result in the confirmation of the hypothesis that project work fosters the student's learning, leadership and social skills.

- In the composition of the working groups, the students belonged to different levels of achievement;

- Of the three students in the history group, two of the students were above the average, while one of them was below the average, but it was noticed that this student had brought interesting legends of the Zone. Through his assertion, it is noticed that he has used the positivists with the close relationship with his grandparents, who have confessed to their grandson legends.

- Out of the three drawers of the drawing group, one of the students, which is below the average achievement level, chosen as the leader of the group, has the passion for painting and has realized the costume paintings found by the other two members of the group. All three students in this group like paintings.

- Of the four music group students, three of them are undergraduate students below the average level, one of whom is a middle-level student. A group leader was selected by a student with poor academic achievement. All four students have talent music.

- Out of the four language group students, three of them result to be above the average level of achievement, while one of them scores below the average level of achievement, but it resulted to have brought interesting information about how the weddings were organized 50 years ago .

- Through the discovery of relevant videos it was noticed that students within the groups cooperated in harmony with one another, were motivated to work. Despite the different levels of learning outcomes, each contributed to the successful realization of the task assigned;

- Leaders of the drawing and music group, despite their difficulties in the subject, showed good leadership skills;

\section{Analysis and interpretation of research results}


Through this research, as Markham points out (2011), the analysis of data shows that for a comprehensive inclusion of students of different levels of learning achievement in the learning process, for an all-encompassing development of the cognitive and psycho-social learners, productive project learning, as project-based learning is a contemporary, studentcentered approach.

From theoretical findings (Mouse, B, 2014) and data analysis, it is taught that learning based on projects, such as collaborative learning, creates an active learning environment that improves social habits and increases the student's responsibility. In the practical findings, it was noted how the students cooperated with one another and carried out highly charged tasks.

Teaching is a tripolar process (Rather A. R. 2004), which includes the teacher, the student, and the learning situation, and which leads to changing student behavior. Silcock and Brundert (2001) defined student-centered teaching as an approach where the teacher is facilitating and guiding the learning process toward teaching where the teacher exercises control in each direction for achieving the learning objectives. This was also noticed in the project hours, where teachers directed and instructed the students, when needed, especially in time management.

Through research, as noted by Blumenfeld et al 1991, it was noted that each one had acquired new knowledge through the project, exploring and discussing with one another. This was noted through student discussions on issues and subissues addressed at the discussion hours of the collected materials and on the hour of presentation of each group's work.

\section{Conclusions}

From the results of this empirical study, it was found that project - based learning positively influences not only the intellectual and psycho - social development of students but also the practical implementation of the knowledge acquired at school. From the research it is concluded that through project-based learning it is possible to:

1. A cooperative learning teacher - learner and learner - student;

2. Project-based learning develops intellectual skills of learners and promotes their critical thinking through discussion of project themes;

3. Develope the students' social skills and develops their self-evaluation skills through the task as a leader of the group;

4. Give another approach to the teacher's role in the classroom, from being a dictator of student information, to facilitating and guiding the learning process. The learner is placed in the learning center.

5. By project-based learning, scientific knowledge is coordinated with their implementation in practice;

6. Students develop the ability of research and problem solving, as well as make pupils' inclusion in the learning process by developing their special skills.

\section{Literature}

[1] Banks, T. (2000). Teaching learning process. Center for Aide Regulation and education. North Carolina

[2] Blumenfeld et al 1991, Educational Psychologist, 26(3\&4) 369-398 "Motivating Project-Based Learning: Sustaining the Doing, Supporting the Learning." Phyllis C. Blumenfeld, Elliot Soloëay, Ronald Ë. Marx,

[3] Joannes Antonin Léonce Joseph Hébrard (dit Jean) est un ingénieur agricole français, né le $\underline{29}$ août 1894 à Laveyrune (Ardèche) et mort le $\underline{23}$ janvier 1943 à Saint-Alban-sous-Sampzon (Ardèche).

[4] Joseph S. Krajcik, Mark Guzdial, and Annemarie Palincsar.

[5] Markham, T. (2011). Project Based Learning. Teacher Librarian, 39(2), 38-42.

[6] Musai, B. Metodologjia mësimore $(2014,278)$

[7] Rather A. R. (2004). Essentials Of Instructional Technology. Publisher, Discovery Publishing House

[8] THE ROADMAP, Dimensions of Teaching and Learning Teaching and Learning Branch, Education Queensland, May 2011, f. 9, 10. 